\title{
Introduction: The North and the First World War
}

\author{
Brent Slobodin \& Ken Coates \\ Co-Chairs, The North and the First World War Conference
}

When war broke out in Europe in 1914, few places in the world had more reasons to ignore the gathering storm than the Yukon and the vast expanses of the Canadian North and Alaska. With a small and declining population, and with global understanding of the territory shrouded in fading memories of the world's greatest gold rush, the Yukon was hundreds of kilometres away from the closest Canadian city of substantial size. A telegraph connection ensured ready updates from the battlefront, but the residents of the Far Northwest corner of Canada would have been excused if they had given a pass to the nationalistic passions of 1914.

But they did just the opposite. Yukoners and other residents of the farflung areas of the British Empire and Allied countries embraced the First World War with patriotic fervour. Young men enlisted in large numbers to the extent that the regional economy suffered grievous harm. Citizens contributed disproportionately to war-bond drives and patriotic funds. Women organized in large numbers to promote military enlistment and to support the troops overseas. Far from ignoring the First World War, northerners threw themselves wholeheartedly into the Allied war effort.

The enthusiasm for the war effort across the North has long puzzled historians. In May 2016, the Yukon Historical and Museums Association (YHMA) and the International Centre for Northern Governance and Development of the University of Saskatchewan, in partnership with Yukon College, combined to host a remarkable four-day conference in Whitehorse, Yukon. A Connection Grant from the Social Sciences and Humanities Research Council of Canada made the event possible. Under

The Northern Review 44 (2017): 3-8 
the guidance of Dr. Brent Slobodin and Dr. Ken Coates, the organizing team reached out to scholars and public historians across Canada, the United States, Great Britain, and as far away as New Zealand and Romania, recruiting them to participate in the gathering. The response was overwhelming. It turns out that Yukoners are not the only people curious about the intense and sustained war effort of people living in the more remote parts of the Allied world.

Northern history and the experience of other remote regions is far more complex than most people assume. The history of the Yukon, for example, is typically reduced to three unrelated events: the Klondike Gold Rush, 1896-1900; the construction of the Alaska Highway, 1942-1946; and the launch of the Yukon First Nations' land claims process, starting in 1973. The territory is largely ignored in the nation's history books, even including these three critical events; other northern regions, from northern Ontario through to the Mackenzie River Valley and northern British Columbia, attract even less interest. So it is with Alaska-which unfairly rests far outside the North American historical mainstream - and rural New Zealand, and the outback of Australia. The conference on "The North in the First World War" was held, first and foremost, to educate northerners about their role during one of the seminal events in modern history. But a secondary goal, well demonstrated at the conference and in the collection of papers in this volume, was to show the broader historical and cultural world that the wartime experiences of remote, peripheral regions should be recognized as an integral part of the attempt to understand the world at war.

The conference was launched by a superb presentation by Canada's foremost military historian, Dr. Tim Cook of the Canadian War Museum, whose rousing and erudite overview provided a vital framework for the rest of the meeting. Historians of the Yukon met with Alaska and British Columbian scholars. Military historians shared the podium with scholars of Yukon politics and northern culture. Academics, public historians, local specialists, and cultural analysts brought dozens of unique and important perspectives. The enthusiasm of the presentations was matched by the quality of the contributors' research and analyses. The North was well served by the conference speakers, as it had been by the soldiers and their supporters during the First World War.

And the conference had more than paper presentations on offer. Preceding the conference, Sarah Murray and others provided an excellent full-day workshop on "Cultural Organizations and the Remembrance of Traumatic Events" at the Yukon Transportation Museum. The discussions 
will undoubtedly inform the work of northern archivists and museum specialists for years to come. On the first night of the conference, attendees were hosted by the MacBride Museum of Yukon History, which holds one of the Yukon's largest collections in its facility. The next day, they attended the opening of a new exhibition mounted by the YHMA, and at a wreath laying at Whitehorse City Hall to remember the Yukon soldiers who fell during the war. At the end of the Whitehorse gathering, the YHMA led a study tour to Dawson City - a community undermined by the transitions of the First World War-so that participants could visit the site of the world-famous gold rush.

The conference was, in every respect, a remarkable scholarly event, made richer by superb organizational efforts of the Yukon Historical and Museums Association and the unrelenting hospitality of the good citizens of Whitehorse. This collection of conference papers captures a great deal of the energy and excitement of the Whitehorse gathering. It cannot, of course, replicate the relaxed and open sharing of ideas that characterized the meeting. The volume includes most of the presentations made at the Whitehorse gathering. The papers cover a wide range of topics and bring a variety of perspectives to bear on the subject. Collectively, the essays document both the complexity of the Yukon at war and the broader comparative context of other remote regions during the First World War.

The wartime experience of the Yukon is outlined by Michael Gates, an accomplished northern writer and historian. He documents the multiple ways in which Yukoners connected to the overseas conflict. Sally Robinson, long-time Yukon public historian, looks beyond military affairs to examine the ways the people of the Yukon understood and responded to the European war, and to describe the severe economic malaise that hit the territory during and after the war. Peter Kikkert of Sheridan College and Whitney Lackenbauer of St. Jerome's University provide an insightful paper on Dawson City's remarkable contributions to the Canadian Yukon Patriotic Fund, a commitment that Yukoners did not feel was adequately recognized by the country at large. Kathy Jones-Gates, an independent Yukon historical researcher, delivers a portrait of the many wartime contributions, in both Dawson and Great Britain, of Martha Black, wife of then Commissioner George Black.

The military side of the North's contribution is examined in several papers. Max Fraser, currently pursuing a film on the prominent Yukoner, Joe Boyle, reflects on various efforts to explain the life history of this unique entrepreneur, patriot, and wartime hero, including his complex relationship with Queen Marie of Romania. Dr. Crina Bud of York University discusses 
Joe Boyle's experiences in Romania and his diplomatic strategies in Europe during the war. Cameron Pulsifer, emeritus curator at the Canadian War Museum, follows the story of the Yukon Motor Machine Gun Battery from its formation in Dawson City through to their challenging experience in trench warfare in Europe. Timothy Popp brings his long-time interest in military awards to his illustrated essay on Canadian Expeditionary Force badges and medals associated with the Yukon.

While the collection as a whole speaks to the broad themes of the North during the First World War, the individual papers also address questions of more specialist interest. The dynamic duo of Peter Kikkert and Whitney Lackenauer provide a provocative analysis of the nature of masculinity and "manliness" on the Northwest frontier, connecting this important social construct with the gold rush and the Yukon's wartime experience. Edward Cowan, from the University of Scotland, brings his long-standing personal interest in the work of famed Yukon poet Robert Service to bear on the study of Service's wartime poems. Sam Steele, one of the most famous members of the North-West Mounted Police and a highly regarded Yukon presence, served in the Canadian army during the First World War; his fascinating career, one that foundered in the straightened and complex military conditions in Europe, is explored by William Stewart.

Historians of other northern regions bring invaluable perspectives to this collection. On a broad canvas, Preston Jones of John Brown University outlines the historical relationship between Great Britain and the United States in the Far Northwest between Confederation and the American purchase of Alaska in 1867, and the end of the First World War in 1918. Lee Huskey, highly regarded Alaskan economist, shares a fascinating analysis of the "fragility" of northern economic life, using the First World War and the writings of Jack London to frame his analysis. The contribution from Mark Zuehlke, an historian interested in northern British Columbia, focuses on Cy Peck, a Prince Rupert entrepreneur who, like Joe Boyle, recruited young men from the region for overseas service. From the same region, historian Maureen Atkinson uses a series of memoirs and personal narratives to document the manner in which the First World War shaped Northwest British Columbia. University of Western Ontario historian Peter Krats demonstrates how the wartime need for nickel had economic, environmental, and social impacts on Sudbury and northern Ontario. Other papers reach further afield for learning opportunities. Sarah Murray of the Canterbury Museum provides an overview of New Zealand's participation in the war and, more specifically, of how the 
country has remembered and commemorated its wartime experiences. Sarah Cook, an archivist with Library and Archives Canada in Ottawa and specialist in audiovisual records, discusses the story of archival footage from the Canadian Arctic Expedition in 1913-1916, examining Canada's evolving fascination with the Far North. Ross Coen, doctoral candidate at the University of Washington, presents a fascinating story of the complex and occasionally contradictory process of bringing Pacific Northwest canned salmon to Europe during the First World War.

Not all of the presentations at the conference are represented in this collection, including the excellent lectures by Tim Cook, Terrence Cole, Dave Neufeld, Nick Gillen, and David Leverton. And, as yet, we have found no way to capture the excellent exchange of ideas, information, and enthusiasm for the North that occurred during social events and over meals. But participants agreed that the conference had rewritten the history of the North in the First World War and had demonstrated the value of comparing Yukon experiences with those in other remote and peripheral regions.

The Northern Review, the multidisciplinary journal published by Yukon College, has kindly agreed to publish the conference proceedings. We are confident that you will enjoy the diversity of ideas, the many different topics, and the unique perspectives offered on a topic that has been ignored for too long. Yukon historians have known that wartime developments transformed the post-Klondike Northwest and set the territory on a different and enfeebled path. Scholars of other remote regions have likewise known that their areas of study were shaped by engagement in a distant conflict. The lectures presented at "The North in the First World War" conference made it clear that the war had profound effects on the Yukon and other regions. The meeting itself demonstrated the immense value in bringing together academics, public historians, and cultural analysts to reflect on a single, comparative theme. Participants left the Yukon gathering with a single request: that the Yukon Historical and Museums Association and its partners organize a second and comparable northern meeting. Discussions are underway.

The North and The First World War conference would not have been possible without the commitment, energy, and ideas of the organizing committee, skilfully coordinated by Kelly Proudfoot, YHMA conference coordinator. The committee membership included Nancy Oakley, Dan Davidson, Joanne Lewis, Max Fraser, Michael Gates, Piers McDonald, Sally Robinson, and Marius Curtenau. Sherilee Diebold-Cooze, executive assistant to Ken Coates in the Johnson-Shoyama Graduate School of Public 
Policy, provided excellent logistical support and somehow managed to get all of the outside speakers to Whitehorse! Paula Chistie of the International Centre for Northern Governance and Development provided invaluable help with the application for conference funding. The support from the Social Sciences and Humanities Research Council of Canada's Connection Grant competition, the Yukon Community Development Fund, and the Yukon Department of Tourism and Culture is gratefully acknowledged, as is the support from Veterans Affairs Canada for this publication. The members of "The North and the First World War" organizing committee were exceptionally pleased to be recognized by the Yukon Historical and Museums Association with the 2016 Helen Couch Volunteer of the Year Award.

\section{Guest Editors}

Brent Slobodin and Ken Coates

Co-Chairs, The North and the First World War Conference

Brent Slobodin lives in Whitehorse; he holds a PhD in twentieth century Canadian political history.

Ken Coates is professor of history and holds the Canada Research Chair in Regional Innovation at the Johnson-Shoyama Graduate School of Public Policy at the University of Saskatchewan in Regina. 